\title{
Teologi Terapan dalam Islam: Sebuah Syarah Hadis dengan Pendekatan High Order Thinking Skill
}

\author{
Wahyudin Darmalaksana1*, Bambang Qomaruzzaman² \\ 1,2Fakultas Ushuluddin UIN Sunan Gunung Djati Bandung, Indonesia \\ Email: yudidarma@uinsgd.ac.id
}

\begin{abstract}
This study aims to discuss the high order thinking skill approach in the sharah hadith method with regard to contemporary issues for the formulation of applied theology. This research method uses a qualitative type through literature study by applying the high order thinking skill approach. The results and discussion of this research include sharah hadith about kalam, tauhid science to applied theology, and from theology to service according to the high order thinking skill approach. The conclusion of this study is that the high order thinking skill approach allows to be applied in the sharah hadith method with regard to contemporary issues for the formulation of applied theology. This study recommends the urgency of applying high order thinking skills as a research approach to contemporary issues in Islamic diversity.
\end{abstract}

Keywords: Applied theology; Bloom's taxonomy; Syarah hadith.

\begin{abstract}
Abstrak
Penelitian ini bertujuan membahas pendekatan high order thinking skill dalam metode syarah hadis berkenaan dengan isu-isu kontemporer bagi perumusan teologi terapan. Metode penelitian ini menggunakan jenis kualitatif melalui studi pustaka dengan menerapkan pendekatan high order thinking skill. Hasil dan pembahasan penelitian ini meliputi syarah hadis tentang kalam, ilmu tauhid menuju teologi terapan, dan dari teologi ke pelayanan menurut pendekatan high order thinking skill. Kesimpulan penelitian ini adalah pendekatan high order thinking skill memungkinkan diterapkan dalam metode syarah hadis berkenaan dengan isu-isu kontemporer bagi perumusan teologi terapan. Penelitian ini merekomendasikan urgensi penerapan high order thinking skill sebagai pendekatan penelitian isu-isu kontemporer dalam keberagamaan Islam.
\end{abstract}

Keywords: Taksonomi Bloom; Teologi terapan; Syarah hadis.

\section{PENDAHULUAN}

Teologi terapan dalam diskursus Islam kontemporer bukan merupakan hal yang asing. Pada tahun 2003 ditemukan diskursus yang menyerukan teologi terapan dalam Islam (M. A. Syukur, 2003). Demikian halnya dengan high order thinking skill (HOTS), ia bukan subjek yang asing pula. HOTS sebagai sebuah pendekatan (Anderson, 2001) sering diterapkan pada dunia pendidikan di Indonesia belakangan ini (Subadar, 2017). Syarah hadis pun sering didengar sebagai sebuah metode dalam pengkajian hadis (Zahrah, 2020). Namun, teologi terapan sebagai diskursus kontemporer ditinjau berdasarkan metode syarah hadis dengan pendekatan HOTS merupakan subjek baru, yang dalam hal ini menjadi fokus penelitoan.

Hadis adalah apapun yang dari Nabi Saw. (Soetari, 1994), tentu selain dari al-Qur'an. Sebab, alQur'an dari Allah Swt., meskipun melalui Nabi Saw. pula. Umat muslim mengakui perilaku Nabi Saw. sebagai ahlak al-Qur'an (Darmalaksana, 2020b). Hadis dipahami sebagai petunjuk kehidupan muslim, dan ia disepakati oleh umat Islam sebagai sumber kedua setelah al-Qur'an (Darmalaksana et al., 2017). Dengan demikian, memahami hadis untuk pentunjuk praktis kehidupan muslim bermakna pelaksanaan al-Qur'an.

*Corresponding Author

Received: October 23, 2019; Revised: November 25, 2020; Accepted: December 29, 2020 
Al-Qur'an lebih banyak memberikan penjelasan secara global (R. Anwar, 2002), sedangkan hadis menjadi petunjuk praktisnya. Berkenaan dengan ini, pada zaman klasik, ada ulama yang mengatakan tidak perlu merujuk hadis, yang belum tentu keabsahannya benar dari Nabi Saw., dan langsung saja merujuk alQur'an yang jelas terjaga (Darmalaksana et al., 2017). Akan tetapi, pengikut Imam al-Syafi'i, Syafi'iyah, lebih memilih hadis untuk hal-hal yang tidak dijelaskan secara terperinci di dalam al-Qur'an. Sejalan dengan ini, berkembanglah metode syarah hadis di dunia intelektual muslim (Taufik, 2020).

Sejumlah orientalis menyebutkan, ketika Islam sampai pada puncak kejayaannya tidak lain merupakan peradaban hadis, lebih tepatnya peradaban fiqih (Darmalaksana, 2004). Fiqih merupakan produk penalaran ulama didasarkan al-Qur'an dan hadis. Fiqih meliputi anturan praktis pelaksanaan Islam. Menurut sejumlah orientalis, fiqih pada dasarnya adalah hadis (Darmalaksana, 2004). Untuk tidak bermaksud membenarkan pandangan orientalis (Karim, 2015), memang terdapat hubungan yang erat antara fiqih dan hadis. Akan tetapi, hadis dan fiqih dapat dibedakan dengan tegas. Fiqih mengenalkan penalaran (ijtihad) sedang hadis disandarkan pada Nabi Saw. Beberapa tema fiqih memang tidak lain merupakan hadis. Terlebih lagi, hadis dalam keilmuan hadis ('ulum al-hadits), ada pula yang berasal dari selain Nabi Saw. (Soetari, 2005), yaitu hadis mawquf dan hadis maqthu'. Hadis mawquf bersandar pada Sahabat, dan hadis maqthu' bersandar pada Tabi'in. Selebihnya, memang ahli hadis dan ahli fiqih tidak bisa dipisahkan (Hosen \& Musyafiq, n.d.). Di masa klasik, ahli fiqih pasti ahli hadis (Rodliyana, 2012). Kecuali di era sekarang, ilmu hadis dan ilmu fiqih telah dilembagakan sendiri-sendiri. Tegasnya, berbeda antara hadis dan fiqih, hadis merupakan sumber Islam, termasuk sumber teologi (Sy, 2017).

Teologi Islam merupakan subjek yang lain lagi. Ia merupakan bidang yang membicarakan keyakinan kepada Allah Swt. (Saparuddin, 2020), termasuk topik perbuatan baik dan perbuatan buruk (Mahmud, 2016). Teologi Islam mengajarkan keyakinan kepada Allah Swt. sebagai syaratiman (Toshihiko \& Husein, 1994). Sebaliknya, mereka yang tidak beriman berarti kufur (Ishak, 2002), yakni tidak mengakui ke-Maha-Kuasa-an Allah Swt. Dalam hal ini, orang berbuat baik implikasinya pahala dan orang berbuat jahat imbalannya dosa. Ada pandangan bahwa perbuatan baik dan perbuatan jahat tidak perlu dirujuk dari Kitab Suci, al-Qur'an dan hadis (Kodir, n.d.), sebab hal itu bisa langsung diketahui melalui penalaran logis manusia. Meskipun pada kenyataannya tersebar hadis-hadis seputar teologi (Siti, 2016) atau syarah hadis perspektif teologis (Suryadilaga, 2013). Tema teologis telah menghasilkan perdebatan yang panjang dalam pergulatan sejarah aliran teologi Islam (H. R. an Rusli, 2019). Sehingga konsekuensi dari perdebatan filosofis (Afrizal et al., 2006) yang melelahkan tersebut (Husain, 2015) seakan-akan teologi tidak memikirkan aspek-aspek praktis dari keimanan (Latif, 2019). Akan tetapi, hal ini tidak serta-merta penerapan keimanan secara praktis merupakan tanggung jawab hadis dan fiqih. Kenyataannya, timbul trend teologi baru dalam Islam (Giling, 2019), yang lebih praktis (S. Syukur, 2014) dalam penerapan (M. A. Syukur, 2003).

HOTS, kepanjangan dari high order thinking skill, merupakan sebuah pendekatan, bahkan strategi. Pendekatan ini dikembangkan sebagai revisi terhadap taksonomi Bloom (Anderson, 2001). Penerapan pendekatan ini memuncak di Indonesia akhir-akhir ini (Subadar, 2017). Pendekatan ini memberikan pandangan tentang keterampilan berpikir tingkat tinggi. Saat ini, HOTS digunakan untuk menggantikan strategi konvensional dalam naungan LOTS (low order thinking skill) di sejumlah institusi pendidikan, bahkan hingga di sekolah tingkat dasar di Indonesia (Arif \& Yuhdi, 2020). HOTS biasanya diterapkan untuk melatih pemecahan masalah (problem solving) secara kritis, kreatif, dan konkrit terhadap persoalanpersoalan real yang tengah dihadapi (Ballakrishnan \& Mohamad, 2020). Bagi orang beriman, pemecahan suatu masalah pasti mengharuskan tersedianya landasan nilai-nilai dan prinsip agama. Salah satu sumber Islam adalah hadis (Darmalaksana et al., 2017), dan dasar keyakinan Islam ialah teologi Islam (Ishak, 
2002), sehingga penerapan HOTS terhadap berbagai problem baru yang dihadapi umat muslim memungkinkan dihasilkannya sebuah pemecahan praktis.

Berdasarkan paparan di atas, penilitian ini berusaha merumuskan formula penelitian, yaitu rumasan masalah, pertanyaan penelitian, dan tujuan penelitian (Darmalaksana, 2020a). Rumusan masalah penelitian ini adalah terdapat pendekatan HOTS yang dapat digunakan dalam syarah hadis untuk merumuskan teologi terapan. Pertanyaannya ialah, bagaimana pendekatan HOTS dalam penggunaan syarah hadis untuk kebutuhan tersebut. Tujuan penelitian ini yaitu membahas pendekatan HOTS dalam penggunaan metode syarah hadis berkenaan dengan isu-isu kontemporer bagi perumusan teologi terapan dalam Islam. Penelitian ini diharapkan memiliki implikasi manfaat bagi pengembangan metode syarah hadis dan sekaligus menemukan bentuk teologi terapan dalam Islam.

\section{METODE PENELITIAN}

Metode penelitian ini menggunakan jenis kualitatif melalui studi pustaka (Darmalaksana, 2020c) dengan menerapkan pendekatan HOTS (Anderson, 2001).

\section{Gambar 1. Indikator HOTS}

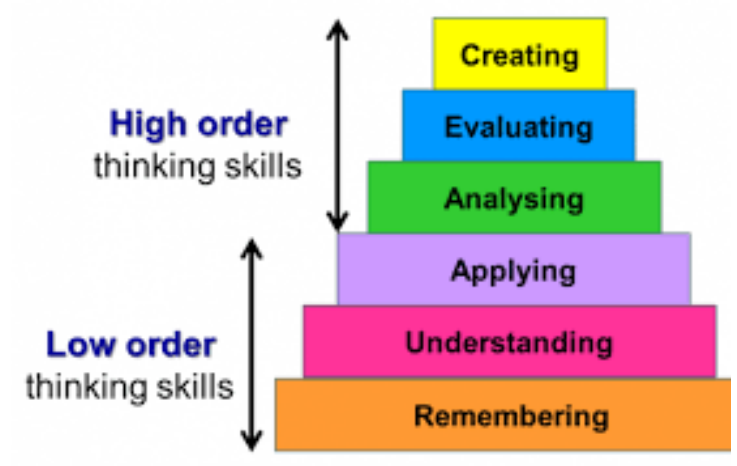

Gambar 1 merupakan indikator HOTS (Anderson, 2001), yaitu menganalisis (analysing), mengevaluasi (evaluating), dan mengkreasi (creating) (Subadar, 2017).

\section{Menganalisis}

a. Analisis informasi ke dalam bagian yang lebih kecil untuk mengenali pola dan hubungan;

b. Mengenali dan membedakan faktor penyebab dan akibat dari sebuah skenario; dan

c. Mengidetifikasi atau merumuskan pertanyaan.

\section{Mengevaluasi}

a. Memberikan penilaian terhadap solusi, gagasan, dan metodologi dengan menggunakan kriteria yang cocok atau standar yang ada untuk memastikan nilai efektivitasnya;

b. Membuat hipotesis, mengkritik dan menguji; dan

c. Menerima atau menolak hipotesis berdasarkan kriteria yang telah menjadi standar. 


\section{Mengkreasi}

a. Membuat generalisasi suatu idea atau cara pandang terhadap sesuatu;

b. Merancang suatu cara untuk menyelesaikan masalah; dan

c. Mengorganisasikan unsur-unsur atau bagian-bagian menjadi struktur baru yang belum pernah ada sebelumnya.

Proses mengingat (remembering), memahami (understanding), dan menerapkan (applying), dari taksonomi Bloom (Gunawan \& Palupi, 2016), dalam perkembangan lebih lanjut dikategorikan dalam recalling. Sedangkan menganalisis, mengevaluasi, dan mencipta dikategorikan dalam transferring atau processing. Belajar untuk transfer merupakan belajar bermakna yang menggunakan proses kognitif lebih rumit (Subadar, 2017). Menganalisis dan mengevauasi digolongkan ke dalam berpikir kritis (critical tinking), sedangkan menciptakan digolongkan ke dalam creative thinking (Anderson, 2001).

\section{HASIL DAN PEMBAHASAN}

\section{Syarah Hadis tentang Kalam}

Syarah hadis berarti penjelasan hadis, baik model klasik maupun model modern (Zahrah, 2020). Metode syarah model klasik (Kurniati, 2020) meliputi ijmali (global), tahlili (kritis), dan muqaran (komparatif). Adapun metode syarah model modern berkenaan dengan isu-isu kontemporer (HS \& Faizah, 2020), biasanya menggunakan pendekatan mutakhir (Taufik, 2020), seperti antopologi (Suryadilaga, 2017), sosiologi, hermeneutika (Zahrah, 2020), dan lain-lain.

Pengertian "kalam" dalam diskursus teologi (Nasir, 2010) berarti "perkataan Allah" (kalamullah), yang dalam diskursus asal-usul fiqih (Auda, 2015) berarti "maksud-maksud Allah" (maqasyid Syariah). Dalam sejarah Islam, pemikiran kalam berkembang menjadi ilmu kalam (Nasir, 2010) atau yang populer dengan ilmu tauhid, ilmu tentang kemahaesaan Allah Swt. (Syafii, 2017). Ilmu kalam atau ilmu tauhid berikutnya berkembang menjadi teologi Islam (Syafii, 2017), yang membicarakan tentang keimanan kepada Allah Swt. (Toshihiko \& Husein, 1994).

Berikut syarah hadis berkenaan dengan keimanan Islam dengan pendekatan maudhu'i (tematik), yakni salah satu pendekatan yang lazim digunakan dalam tafsir al-Qur'an (Yamani, 2015). Metode ini secara operasional berarti menghimpun teks berdasarkan tema sehingga membentuk pandangan konsepsional (R. Anwar, 2002). Untuk selanjutnya, hadis-hadis ini dikaitkan dengan isu-isu kontemporer (Wendry et al., 2018).

Tabel 1 menunjukan nomor 1 (satu) hadis tentang iman meliputi iman kepada Allah, malaikat, Kitab, Rasul, dan takdir. Nomor 2 (dua) memberikan harta sebagian dari iman. Nomor 3 (tiga) kesempurnaan iman mencakup pemberian hal yang dicintai kepada saudara. Nomor 4 (empat) keimanan berarti menjaga amanah. Nomor 5 (lima) menyingkirkan ganguan dari jalan dan sifat malu bagian dari iman. Nomor 6 (enam) toleransi merupakan aktualisasi iman serta untuk tidak kikir dan antipati. Terakhir, nomor 7 (tujuh) memelihara kebersihan lingkungan merupakan tonggak iman. 
Khazanah Theologia, Vol. 2 No. 3: 119-131

Teologi Terapan dalam Islam: Sebuah Syarah Hadis dengan Pendekatan High Order Thinking Skill Wahyudin Darmalaksana

\section{Tabel 1 Tematik Hadis tentang Iman}

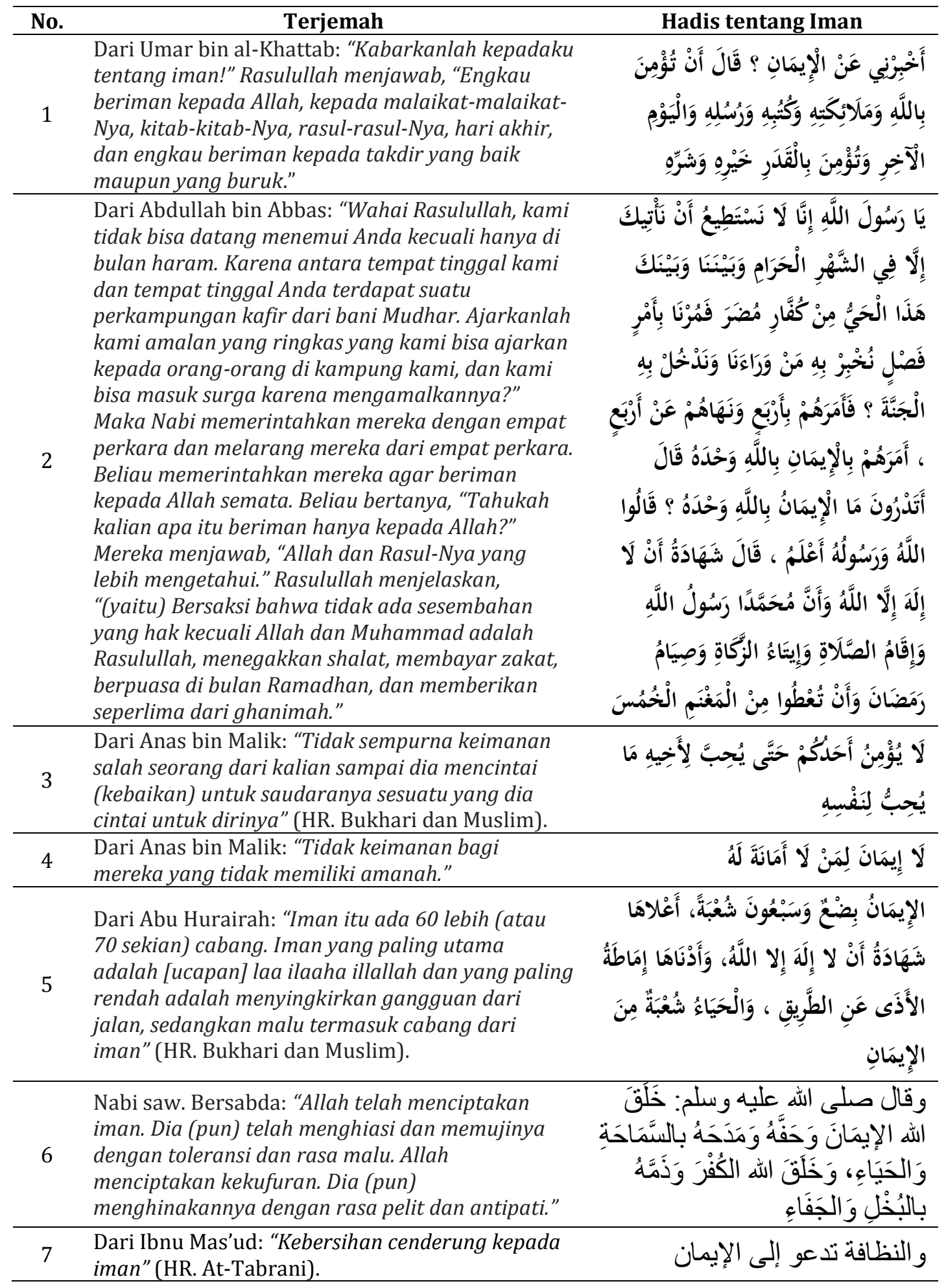


Hadis tentang iman bila dikumpulkan maka tidak akan ada habisnya (Ismail, 2002). Para ulama telah menghimpun hadis-hadis tentang iman dalam kitab khusus yang berjilid-jilid dalam bab-bab tersendiri (Zabidi, n.d.). Misalnya Imam As-Suyuthi dalam Lubabul Hadits, at-Tijan Fi Syu'abil Iman Karya Imam Ghazali (Puspitasari, 2019), dan Syu'bul Iman karya Syaikh Muhammad Nawawi (Farihat, 2017). Para ulama memberikan syarah terhadap hadis-hadis tersebut (Sulaemang, 2016) berikut asbab al-wurud hadis (Muin, 2015). Hadis idealnya dilakukan takhrij (Jannah, 2017) dan kemudian syarah (Soetari, 2015). Diakui bahwa hadis tentang iman kepada Allah Swt. dikategorikan sahih (Kamiludin, 2015). Meskipun pada dasarnya hadis yang menurut penalaran logis merupakan fadha'il al-amal (amal kebaikan) tidak perlu dilakukan takhrij (Yusram, 2017). Selebihnya, khabaryang disandarkan kepada Sahabat atau Tabi'in tetap disebut hadis (Soetari, 2005). Ihwal kebersihan sebagai bagian dari iman diakui bukan hadis (Erwan, 2008), tetapi merupakan anjuran amal kebaikan dari ulama (Yusram, 2017), sehingga dapat dikategorikan hadis (Soetari, 2005).

Hadis tentang iman bukan hanya metaphor mengenai Tuhan (Sudarsono, 2016), tetapi dapat diinterpretasi (Kholid, 2017), diinternaslisasi (Rahman, 2019), dan direformulasi (Abidin, 2003), di antaranya sebagai materi dalam pendidikan (Anugrah et al., 2019). Hal ini berguna untuk peningkatan prestasi belajar (Jamzuri, 2011) dan terlebih lagi untuk kepentingaan transformasi teologis (Bakri, 2016) berkenaan dengan isu-isu kontemporer (Wendry et al., 2018).

\section{Menuju Teologi Terapan}

Saat ini tengah berlangsung diskursus trend teologi baru dalam Islam (Giling, 2019). Hal ini dipahami sebagai rekonstruksi teologi Islam kajian kritis melalui usaha-usaha pembaharuan menuju teologi praktis (S. Syukur, 2014). Diakui memang teologi Islam mengalami transformasi dalam lintasan sejarah (Bakri, 2016), baik di lingkup dunia (Muarif \& Yunus, 2019) maupun di nusantara (Gazali, 2019). Para ahli teologi, tidak lagi membincangkan perbandingan iman dan kufur di antara aliran teologi (Ishak, 2002), yang biasanya menjadi perdebatan utama dalam teologi Islam (Afrizal etal., 2006). Dewasa ini, para ahli telah berusaha membincang ulang teologi Islam klasik dalam dunia kontemporer (Latif, 2019). Sehingga terpetakanlah paradigma pemikiran teologi Islam klasik dan modern (Abbas, 2015).

Sejalan dengan diskursus teologi Islam Modern (Sahal \& Aziz, 1999), timbul sejumlah kajian teologis. Antara lain Islam mulai dihubungkan dengan teologi pembebasan (Firdawati, 2004). Ada pula kajian seputar liberalisasi teologi Islam sebagai ikhtiyar membangun teologi damai dalam Islam (Engineer, 2004). Hal ini bisa jadi sebagai counter terhadap teologi radikalisme di Indonesia untuk rekonstruksi menuju Islam rahmatan lil alamin (Asmani, 2017). Kenyataannya menjamur upaya reorientasi teologi Islam dalam konteks pluralisme beragama (Mustafa, 2006). Suatu pandangan yang menghendaki tumbuhnya teologi kerukunan beragama di Indonesia (Ghazali, 2013). Perkembangan ini tidak terlepas dari usaha-usaha melakukan konstruksi secara paradigmatis mengenai pemikiran teologi Islam kritis (Abas, 2016). Dalam hal ini, teologi Islam secara metodologis menganut pandangan kontekstual dan transformatif (Said, 2013).

Perkembangan pemikiran teologi Islam tidak bisa dilepaskan dari peran para tokoh (H. R. an Rusli, 2019). Untuk menyebutkan beberapa saja, misalnya Hassan Hanafi asal Mesir tetapi bermukim di Eropa yang terkenal dengan pemikirannya yakni konstruksi teologi revolusioner (L. Hakim, 2010). Tokoh bernama Mohammed Arkoun juga terkenal getol membumikan teologi Islam dalam kehidupan modern (Latif, 2015). Selebihnya, Muhammad Syahrur berusaha pula melakukan reformulasi Islam dan Iman (Abidin, 2003). Dalam hal ini, Harun Nasution disebut-sebut sebagai orang yang memulai mewacanakan teologi rasional dan sekaligus praksis di Indonesia (Halim, 2001). Memang peran pemikiran teologi Islam 
Harun Nasution tampak berpengaruh dalam pemikiran pembaharuan Islam di Indonesia (Agung, 2019). Hanya saja, Fazlur Rahman, intelektual muslim asal Pakistan, lebih berperan melalui kajiannya tentang teologi Islam dihubungkan dengan pembacaan teks Suci, Al-Qu'an dan Hadis, termasuk fiqih modern (H. Anwar, 2014). Dari Fazlur Rahman ada tawaran metodologis dalam teologi Islam (Harianto, 2016).

Sejumlah tokoh terkemuka pada dasarnya menghendaki sebuah reorientasi kajian teologi Islam sebagai ikhtiar kontributif atasi problem kekinian (M. Rusli, 2012). Kajian kontemporer umumnya memandang urgensi studi teologi sosial Islam (Kamal, 2019). Teologi sosial dipahami sebagai keniscayaan untuk keberagamaan yang Islami berbasis kemanusiaan (Rakhman, 2013). Di antaranya juga anjuran kajian teologi Islam dan solusi bagi realitas ketimpangan sosial (Jihad, 2016). Bahkan, ada yang secara tegas menyatakan istilah teologi Islam terapan, yakni sebagai upaya antisipatif terhadap hedonisme kehidupan modern (M. A. Syukur, 2003).

Studi teologi Islam pada gilirannya tidak heran mengahsilkan ide-ide yang spesifik dan konkrit. Antara lain teologi tanah yang merupakan gagasan teologis Hasan Hanafi (Alfijihad, 2009). Teologi lingkungan hidup dalam perspektif Islam (Fata, 2015). Refleksi filosofis atas teologi Islam mengenai lingkungan dan pelestariannya (Roswantoro, 2016). Teologi konstruktif atasi krisis lingkungan (Quddus, 2012). Kontekstualisasi teologi sebagai basis gerakan ekologi (Khitam, 2016). Kontekstualisasi teologi Islam sebagai basis regulasi ekologi transendensi (Nurhayati, 2018). Teologi lingkungan dalam kearifan lokal masyarakat Sunda (Suyatman, 2018). Pemahaman hadis tentang bencana sebagai kajian teologis terhadap hadis-hadis tentang bencana (Suryadilaga, 2013). Di antaranya juga penelitian teologi bencana perspektif hadis (Parwanto, 2019b).

Dijumpai kajian filosofis yang cenderung abstrak tetapi realistik, yaitu teologi cinta sebagai implementasi doktrin Islam di ruang publik (Qorib, 2018). Hal yang lebih spesifik lagi misalnya teologi advokasi (Mukharrom, 2004). Beberapa melakukan kajian teologis dalam lingkup fiqih, yakni menakar teologi keadilan dalam poligami (Khalik, 2019). Sebelumnya, terdapat kajian teologis terhadap hadis-hadis sosial tentang poligami, sebuah pemahaman hadis tentang poligami (Safitri, 2018). Ditemukan pula penelitian teologi menstruasi berkenaan dengan pembahasan antara mitologi dan kitab Suci (Umar, 1995). Selebihnya adalah kajian konsepsi ideologis akuntansi Islam dalam tinjauan paradigma teologi pembebasan (Ruslan, 2013), hal ini dilanjut dengan penelitian teologi wirausaha (Jalil, 2015).

Teologi Islam telah memulai memasuki wilayah terapan. Kenyataannya, ada penelitian teologi sains sebagai upaya mengatasi dikotomi sains dan agama dalam perspekif Islam (Basri, 2019). Sebelumnya, suatu penelitian telah berusaha mengungkap teologi saintifik Islam sebagai refleksi spiritualitas sains dalam Islam (Badarussyamsi, 2015). Teologi merupakan kategori rumpun ilmu dasar bukan termasuk rumpun ilmu terapan (Bentley et al., 2015). Akan tetapi, kebijakan telah mengarahkan studi Islam, termasuk teologi, untuk mengarah dari penelitian dasar ke penelitian terapan (Tim Penyusun, 2018). Ini sejalan dengan mandat impelementasi integrasi ilmu di lingkungan pendidikan tinggi Islam (Indonesia, 2019).

\section{HOTS dari Teologi ke Pelayanan}

Bagian ini giliran menerapkan HOTS dimulai dari LOTS (low order thinking skill), yaitu mengingat, memahami, dan menerapkan (Arif \& Yuhdi, 2020). Dipastikan umat muslim bukan saja telah mengingat dan memahami, bahkan telah menerapkan aplikasi iman dalam keseharian (Anugrah et al., 2019). LOTS diperiksa melalui HOTS, yakni menganalisis, mengevaluasi, dan mencipta (Anderson, 2001). 
Aktualisasi iman dipastikan bertambah dan berkurang sebagai sifat alamiah manusia (Ardae \& Wan, 2015). Berkurangnya iman bisa disebabkan faktor lingkungan (H. Hakim, 2014). Salah satu pertanyaannnya adalah bagaimana menjalankan iman secara konsinten. Ada banyak jawaban di antaranya membentuk komunitas iman (Utami, 2018). Biasanya pembentukan suatu komunitas (Pujasmara, 2019) terbukti cukup efektif (Rachmiatie et al., 2007). Meskipun membentuk suatu komunitas bukan perkara yang mudah, namun budaya religious pada sebuah komunitas biasanya dapat dikembangkan (Khadavi, 2016). Tentu membentuk suatu komuntas bukan satu-satunya jalan, bisa juga melalui jalan personal secara zuhud (Hamid et al., 2016). Hanya saja aktivitas personal tidak lebih massif dibandingkan melalui sebuah gerakan (Syaefuddin, 2018).

Beberapa gerakan di antaranya membangun kesadaran inklusif multikultural untuk deradikalisasi pendidikan Islam (Muqoyyidin, 2013). Kampanye sosial gerakan menutup aurat (Firdiyah \& Primasari, 2019). Menghadapi kapitalisme dengan pendekatan eco-sufism melalui gerakan environmentalisme Islam (Imamah, 2017). Gerakan moral dalam upaya revolusi mental (Samad, 2016). Membangun kesadaran warga Negara dalam pelestarian lingkungan (Yuniarto, 2013). Apabila diurutkan maka banyak sekali gerakan kepedulian yang telah menunjukan eksistensinya di dunia. Hal ini tidak bisa dinafikan sebagai bentuk aksiologi nilai-nilai inti iman. Hanya saja gerakan dengan melibatkan banyak massa pun tidak selalu menjadi jalan paling efektif. Sebab, suatu gerakan yang pada mulanya murni aktualisasi iman, tidak menutup kemungkinan terbawa arus gerakan politik. Akhirnya, upaya membumikan nilai-nilai iman menghadapi kendala.

HOTS menghendaki keterampilan berpikir tingkat tinggi, yakni kemampuan untuk menghubungkan dan mengubah pengetahuan dan pengalaman yang dimiliki secara kritis dan kreatif dalam menentukan keputusan untuk menyelesaikan masalah dalam situasi baru, hal ini dilakukan dengan bertumpu pada penalaran, inovasi dan kreativitas untuk menyelesaikan masalah (Arif \& Yuhdi, 2020). Dengan demikian, kata kunci HOTS adalah berpikir kritis dan secara kreatif (Ballakrishnan \& Mohamad, 2020).

Teologi terapan memainkan peranan signifikan. Meskipun hal ini menjadi pekerjaan yang kompleks dalam implementasinya, tetapi penggunaan istilah teologi Islam terapan telah diluncurkan dan upaya-upaya ke arah tersebut telah dimulai (M. A. Syukur, 2003). Teologi terapan menghendaki pendekatan interdisipliner, yaitu analisis dengan ilmu-ilmu lain yang serumpun dan relevan (Rohmatika, 2019). Juga dibutuhkan pendekatan mulitidisipliner, dan bahkan transdisipliner. Pendekatan interdisipliner berarti menggunakan tinjauan berbagai sudut pandang ilmu, meskipun tidak serumpun (Rohmatika, 2019). Adapun pendekatan transdisipliner berarti mengintegrasikan yang multidisipliner secara lintas ilmu (Sudikan, 2015).

Secara interdisipliner berarti aktualisasi teologi terapan dibutuhkan pandangan filsafat Islam, tasawuf, ilmu al-Qur'an, ilmu hadis, fiqih, dan lain-lain. Adapun secara multidisipliner berarti penerapan teologi ini dibutuhkan kolaborasi dengan sains dan teknologi (Basri, 2019).

Himpunan hadis tentang iman dapat dipahami bahwa Allah Swt. merupakan "Pencipta." Adapun manusia adalah "co-Pencipta" di muka bumi. Ini artinya manusia hendaknya menghindari kerusakan di muka bumi (Parwanto, 2019a). Sebagai co-Pencipta, manusia dituntut mengkreasi (Anderson, 2001). Apapun kreasi itu tidak dilihat besar atau kecil, asalkan bermanfaat bagi yang lain, dan bahkan sesuatu yang besar dimulai dari hal yang dianggap spele. Dengan demikian, mencipta secara kritis, kreatif, inovatif, dan produktif untuk kemaslahatan merupakan aktualisasi nilai-nilai inti iman. Harapannya manusia beragama Islam hendaknya dalam hidup keseharian senantiasa dilandasi nilai-nilai inti iman, meskipun hanya memastikan terciptanya sebuah pelayanan kecil bagi yang lain. Dalam perspektif Islam, setiap diri 
adalah khadimul ummah, yakni setiap jiwa ialah pelayan umat. Barangkali dari teologi ke pelayanan inilah yang menjadi hal baru bagi teologi terapan dari metode syarah hadis dengan pendekatan HOTS.

\section{SIMPULAN}

Pendekatan HOTS memungkinkan diterapkan dalam metode syarah hadis berkenaan dengan isuisu kontemporer bagi perumusan teologi terapan. Pendekatan ini memandang bahwa teologi Islam yang sejatinya sakral tetapi juga sekaligus profan. Berdasarkan himpunan hadis tentang iman dapat dipahami secara multak bahwa Tuhan adalah Pencipta, sedangkan manusia co-Pencipta. Sehingga tugas manusia ialah mencipta di muka bumi, yakni mencipta apapun yang maslahat. Sikap kritis, kreatif, dan produktif merupakan inti penerapan iman menurut pendekatan HOTS berdasarkan metode syarah hadis berkenaan dengan isu-isu kontemporer. Penelitian ini diharapkan bermanfaat untuk pengembangan metode syarah hadis, khususnya dalam upaya menuju implementasi teologi terapan. Diakui penelitian ini memiliki keterbatasan hanya pembahasan secara global tentang aksiologi nilai-nilai inti iman, sehingga dibutuhkan penelitian lebih lanjut tentang model teologi terapan yang lebih praktis. Penelitian ini merekomendasikan urgensi penerapan HOTS sebagai pendekatan penelitian isu-isu kontemporer dalam keberagamaan Islam.

\section{REFERENSI}

Abas, Z. (2016). Konstruksi Paradigmatis Pemikiran Teologi Islam Kritis. Al-Tahrir: Jurnal Pemikiran Islam, 12(2), 341-358.

Abbas, A. (2015). Paradigma dan Corak Pemikiran Teologi Islam Klasik dan Modern. Shautut Tarbiyah, 21(1), 1-16.

Abidin, M. Z. (2003). Reformulasi Islam dan Iman: Kembali kepada Tanzil Hakim dalam Perspektif Muhammad Syahrur. Millah: Jurnal Studi Agama, 3(1), 108-122.

Afrizal, M., Ta'yudin, A., \& Mahdi, S. (2006). Ibn Rusyd: tujuh perdebatan utama dalam teologi Islam. Erlangga.

Agung, G. G. (2019). Peran Pemikiran Teologi Islam Harun Nasution Terhadap Pemikiran Pembaharuan Islam di Indonesia. IAIN Kediri.

Alfijihad, Z. (2009). Teologi Tanah: Studi atas Gagasan Teologis Hasan Hanafi tentang Tanah. Master Thesis Graduate School of UIN Sunan Kalijaga, Yogyakarta.

Anderson, L. W. (2001). Krathwohl (Eds.).(2001). A Taxonomy for learning, teaching, and assessing: A revision of bloom's taxonomy of educational objectives. New York: Longman.

Anugrah, R. L., Asirin, A., Musa, F., \& Tanjung, A. (2019). Islam, Iman dan Ihsan dalam Kitab Matan Arba'in An-Nawawi (Studi Materi Pembelajaran Pendidikan Islam Dalam Perspektif Hadis Nabi SAW). Tarbiyah Islamiyah: Jurnal Ilmiah Pendidikan Agama Islam, 9(2).

Anwar, H. (2014). Teologi Islam Perspektif Fazlur Rahman. ILMU USHULUDDIN, 2(2), 125-142.

Anwar, R. (2002). Metode Tafsir Maudhu'i dan cara penerapannya, terj. In Bandung: Pustaka Setia.

Ardae, M., \& Wan, N. M. (2015). Konsep Bertambah dan Berkurang Iman menurut Perspektif Islam. Jurnal Islam Dan Masyarakat Kontemporari, 182.

Arif, S., \& Yuhdi, A. (2020). Integration of High Order Thinking Skills in Research Method Subject in University. Britain International of Linguistics Arts and Education (BIoLAE) Journal, 2(1), 378-383.

Asmani, J. M. (2017). Rekonstruksi Teologi Radikalisme di Indonesia, Menuju Islam Rahmatan Lil Alamin. Wahana Akademika: Jurnal Studi Islam Dan Sosial, 4(1), 3-18.

Auda, J. (2015). Memahami Maqasid Syariah. PTS Islamika.

Badarussyamsi, B. (2015). Spiritualitas Sains Dalam Islam: Mengungkap Teologi Saintifik Islam. MIQOT: Jurnal Ilmu-Ilmu Keislaman, 39(2). 
Bakri, S. (2016). Tarikh Islam: Transformasi Teologi dalam Lintasan Sejarah Peradaban. BukukuMedia.

Ballakrishnan, K., \& Mohamad, M. (2020). Teachers' Teaching Methods in Teaching Higher Order Thinking Skill (HOTS) Comprehension Questions. INTERNATIONAL JOURNAL OF ACADEMIC RESEARCH IN BUSINESS AND SOCIAL SCIENCES, 10(2).

Basri, H. (2019). Teologi Sains: Mengatasi Dikotomi Sains-Agama Perspekif Islam. Jurnal Pemikiran Islam Vol, 5(2).

Bentley, P. J., Gulbrandsen, M., \& Kyvik, S. (2015). The relationship between basic and applied research in universities. Higher Education, 70(4), 689-709.

Darmalaksana, W. (2004). Hadis di Mata Orientalis: Telaah atas Pandangan Ignaz Goldziher dan Joseph Schacht. Bandung: Benang Merah Press.

Darmalaksana, W. (2020a). Formula Penelitian Pengalaman Kelas Menulis. Jurnal Kelas Menulis UIN Sunan Gunung Djati Bandung.

Darmalaksana, W. (2020b). Living Hadis Nilai-nilai Inti Manajemen Strategis Pendidikan Tinggi. Jurnal Ushuluddin UIN Sunan Gunung Djati Bandung, 2.

Darmalaksana, W. (2020c). Metode Penelitian Kualitatif Studi Pustaka dan Studi Lapangan. PrePrint Digital Library UIN Sunan Gunung Djati Bandung.

Darmalaksana, W., Pahala, L., \& Soetari, E. (2017). Kontroversi Hadis sebagai Sumber Hukum Islam. Wawasan: Jurnal Ilmiah Agama Dan Sosial Budaya, 2(2), 245-258.

Engineer, A. A. (2004). Liberalisasi Teologi Islam: Membangun Teologi Damai dalam Islam. Yogyakarta: Alinea.

Erwan, A. (2008). Higienitas perspektif hadis: kajian hadis-hadis tentang kebersihan makanan, sumber air, rumah dan jalanan.

Farihat, I. S. (2017). Amr dalam Kitab Syu'bul Iman karya Syaikh Muhammad Nawawi Studi tentang Balaghah. UIN Sunan Gunung Djati Bandung.

Fata, A. K. (2015). Teologi lingkungan hidup dalam perspektif Islam. ULUL ALBAB Jurnal Studi Islam, 15(2), 131-147.

Firdawati, R. (2004). Islam dan Teologi Pembebasan. Yogyakarta: Pustaka Pelajar.

Firdiyah, R., \& Primasari, W. (2019). Kampanye Sosial Gerakan Menutup Aurat di Bekasi. Jurnal Ilmu Komunikasi, 16(1), 89-101.

Gazali, G. (2019). Teologi Islam Nusantara. PROCEEDING IAIN Batusangkar, 4(1), 109-112.

Ghazali, A. M. (2013). Teologi Kerukunan Beragama dalam Islam (Studi Kasus Kerukunan Beragama di Indonesia). ANALISIS: Jurnal Studi Keislaman, 13(2), 271-292.

Giling, M. (2019). Diskursus Trend Teologi Baru Dalam Islam. Foramadiahi, 11(2), 225-230.

Gunawan, I., \& Palupi, A. R. (2016). Taksonomi Bloom-revisi ranah kognitif: kerangka landasan untuk pembelajaran, pengajaran, dan penilaian. Premiere Educandum: Jurnal Pendidikan Dasar Dan Pembelajaran, 2(02).

Hakim, H. (2014). Pengaruh pemahaman hadis "kebersihan adalah sebagian dari iman" terhadap perilaku kebersihan lingkungan pada santri di Pondok Pesantren Futuhiyyah Mranggen Demak. UIN Walisongo.

Hakim, L. (2010). Konstruksi Teologi Revolusioner Hassan Hanafi. SUBSTANTIA: Jurnal Ilmu-Ilmu Ushuluddin, 12(1), 85-106.

Halim, A. (2001). Teologi Islam rasional: Apresiasi terhadap wacana dan praksis Harun Nasution. Ciputat Press.

Hamid, M. F. A., Suliaman, I. H., \& Ariffin, M. F. M. (2016). The Concept of Zuhud Based on Fiqh AlHadith. Jurnal Intelek, 11(1).

Harianto, B. (2016). Tawaran Metodologi Fazlur Rahman dalam Teologi Islam. Kontemplasi: Jurnal Ilmu-Ilmu Ushuluddin, 4(2), 277-298. 
Hosen, M., \& Musyafiq, A. (n.d.). Urgensi Integrasi Antara Ahli Fiqh dan Ahli Hadis dalam Memahami Sunah: Studi atas Pemikiran Syekh Muhammad al-Ghazali dalam Karyanya al-Sunah alNabawiyah baina Ahl al-Fiqh wa Ahl al-Hadis.

HS, M. A., \& Faizah, F. (2020). Syarah Hadis dalam Bentuk Film: Studi Syarah Hadis 'Keutamaan Salat Shubuh'dalam Film “Cinta Shubuh." Dialogia: Jurnal Studi Islam Dan Sosial, 18(1), 126-145.

Husain, A. (2015). Polemik Aliran Islam Klasik Tentang Iman, Kufur, Akal Dan Wahyu.

Imamah, F. M. (2017). Menghadapi Kapitalisme: Pendekatan Eco-Sufism dalam Gerakan Environmentalisme Islam Indonesia. Kontemplasi: Jurnal Ilmu-Ilmu Ushuluddin, 5(1), 109135.

Indonesia, K. A. R. (2019). Pedoman Implementasi Integrasi Ilmu di Perguruan Tinggi Keagamaan Islam. Direktorat Pendidikan Tinggi Keagamaan Islam Direktorat Jenderal Pendidikan ....

Ishak, M. S. (2002). Konsep Iman dan Kufur: Perbandingan Perspektif antara Aliran Teologi. Jurnal Teknologi, 61-64.

Ismail, A. (2002). Selamat bergumul: 33 renungan tentang iman (Vol. 11). BPK Gunung Mulia.

Jalil, A. (2015). Teologi Wirausaha. Islamica: Jurnal Studi Keislaman, 6(2).

Jamzuri, B. (2011). Upaya meningkatkan prestasi belajar peserta didik pada pembelajaran Aqidah Akhlak materi iman kepada Kitab-kitab Allah SWT melalui model pembelajaran kooperatif tipe jigsaw (studi tindakan kelas di MTs Al Ihsan Doglo Cepogo Boyolali kelas VIII tahun 2010. IAIN Walisongo.

Jannah, D. (2017). Kritik dan Syarah Hadits. Al-Tarbawi Al-Haditsah: Jurnal Pendidikan Islam, 2(1).

Jihad, Z. A. (2016). Teologi Islam dan Solusi bagi Realitas Ketimpangan Sosial. Jurnal Pikir: Jurnal Studi Pendidikan Dan Hukum Islam, 2(2), 194-215.

Kamal, T. (2019). Urgensi Studi Teologi Sosial Islam. Al-Hikmah: Jurnal Dakwah Dan Ilmu Komunikasi, 22-38.

Kamiludin, I. (2015). Kualitas hadis dalam kitab tafsir sya'rawi: Kajian hadis tentang iman kepada hari kiamat. UIN Sunan Gunung Djati Bandung.

Karim, A. (2015). Pemikiran Orientalis terhadap Kajian Tafsir Hadis. Addin, 7(2).

Khadavi, M. J. (2016). Pengembangan Budaya Religius Dalam Komunitas Sekolah. Al-Makrifat: Jurnal Kajian Islam, 1(2), 164-179.

Khalik, S. (2019). Menakar Teologi Keadilan Dalam Poligami. Al-Risalah Jurnal Ilmu Syariah Dan Hukum, 19(1), 57-65.

Khitam, H. (2016). Kontekstualisasi Teologi sebagai Basis Gerakan Ekologi. DINIKA: Academic Journal of Islamic Studies, 1(2), 143-164.

Kholid, A. (2017). Intepretasi Ayat-Ayat Teologis Muhammad Al-Shawkānī Tentang Manusia, Wahyu, Dan Iman. TEOSOFI: Jurnal Tasawuf Dan Pemikiran Islam, 7(1), 172-198.

Kodir, A. A. (n.d.). Teologi dalam Periwayatan Hadis: Analisis terhadap Relasi Ahli Hadis-Qadariyah. Sekolah Pascasarjana UIN Jakarta.

Kurniati, Y. (2020). Rekonstruksi Metodologi Keilmuan Syarah Hadis Klasik. Islam Transformatif: Journal of Islamic Studies, 4(1), 46-56.

Latif, M. (2015). Membumikan Teologi Islam dalam Kehidupan Modern (Berkaca dari Mohammed Arkoun). Bina'Al-Ummah, 10(1).

Latif, M. (2019). Membincang Ulang Teologi Islam Klasik dalam Dunia Kontemporer. Aqidah-Ta (Jurnal Ilmu Aqidah), 5(1), 114-129.

Mahmud, A. (2016). Ke-Jabariah-an dan Ke-Qodariah-an Dalam Tiga Madzhab Besar Teologi Klasik dan Dunia Islam Masa Kini. Qolamuna: Jurnal Studi Islam, 2(1), 57-76.

Muarif, A. S., \& Yunus, M. (2019). Tinjauan Teologi Islam di Dunia. Islamika: Jurnal Ilmu-Ilmu Keislaman, 19(02), 40-53.

Muin, M. (2015). Pemahaman Komprehensif Hadis Melalui Asbab Al-Wurud. Addin, 7(2).

Mukharrom, M. T. (2004). Teologi Advokasi. Al-Mawarid Journal of Islamic Law, 12(11), 26021.

Muqoyyidin, A. W. (2013). Membangun kesadaran inklusif multikultural untuk deradikalisasi pendidikan Islam. Jurnal Pendidikan Islam, 2(1), 131-151. 
Mustafa, M. D. (2006). Reorientasi Teologi Islam dalam Konteks Pluralisme Beragama. HUNAFA: Jurnal Studia Islamika, 3(2), 129-140.

Nasir, S. A. (2010). pemikiran kalam (teologi islam): Sejarah, Ajaran, Dan Perkembangannya.

Nurhayati, N. (2018). Kontekstualisasi Teologi Islam sebagai Basis Regulasi Ekologi Transendensi.

Parwanto, W. (2019a). Teologi Bencana Perspektif Hadis: Mendiskusikan antara yang Menghujat dan yang Moderat. Al-Bukhari: Jurnal Ilmu Hadis.

Parwanto, W. (2019b). Teologi Bencana Perspektif Hadis. Al-Bukhari: Jurnal Ilmu Hadis, 2(1), 6990.

Pujasmara, M. (2019). Bimbingan rohani Islam untuk penguatan komitmen beragama pada Komunitas Majelis Tato: Penelitian di Komunitas Majelis Tato jalan Cijawura Girang IV No 16 Sekejati, Buahbatu, Bandung. UIN Sunan Gunung Djati Bandung.

Puspitasari, D. (2019). Pelaksanaan Pembelajaran Ulumul Hadits Menggunakan Kitab At-Tijan Fi Syu'abil Iman Karya Kh Imam Ghazali Bin Hasan Ustadz Pada Siswa Kelas X Ipa Di Ma Al Islam Jamsaren Surakarta Tahun Ajaran 2018/2019. IAIN SURAKARTA.

Qorib, M. (2018). Teologi Cinta: Implementasi Doktrin Islam di Ruang Publik. Kumpulan Buku Dosen, 1(1).

Quddus, A. (2012). Ecotheology Islam: Teologi Konstruktif Atasi Krisis Lingkungan. Ulumuna, 16(2), 311-346.

Rachmiatie, A., Sidik, A. A., \& Kamil, F. (2007). Proses Sosialisasi Informasi Agama Islam Melalui Media Komunitas Sebagai Pembentuk Moralitas Remaja Muslim. MIMBAR: Jurnal Sosial Dan Pembangunan, 23(1), 121-156.

Rahman, A. I. N. (2019). Internalisasi Nilai-nilai Iman, Ilmu, Dan Amal Melalui Pengajian Kitab Arba'in al-Nawawiyah Di Pondok Pesantren Mamba'ul Hikmah Pasar Pon Ponorogo. IAIN PONOROGO.

Rakhman, A. B. (2013). Teologi Sosial; Keniscayaan Keberagamaan yang Islami Berbasis Kemanusiaan. ESENSIA: Jurnal Ilmu-Ilmu Ushuluddin, 14(2), 161-182.

Rodliyana, M. D. (2012). Hegemoni Fiqh Terhadap Penulisan Kitab Hadith. JOURNAL OF QUR'AN AND HADITH STUDIES, 1(1), 119-144.

Rohmatika, R. V. (2019). Pendekatan Interdisipliner dan Multidisipliner Dalam Studi Islam. AlAdyan: Jurnal Studi Lintas Agama, 14(1), 115-132.

Roswantoro, A. (2016). Refleksi Filosofis atas Teologi Islam Mengenai Lingkungan dan Pelestariannya. Al-Tahrir: Jurnal Pemikiran Islam, 12(2), 219-238.

Ruslan, M. (2013). Konsepsi Ideologis Akuntansi Islam dalam Tinjauan Paradigma Teologi Pembebasan. Skrpsi. Universitas Hasanuddin. Fakultas Ekonomi Dan Bisnis. Akuntansi.

Rusli, H. R. an. (2019). Teologi Islam: Telaah Sejarah dan Pemikiran Tokoh-Tokohnya. Prenada Media.

Rusli, M. (2012). Reorientasi Kajian Teologi Islam: Ikhtiar Kontributif Atasi Problem Kekinian. Ulumuna, 16(2), 223-244.

Safitri, E. (2018). Pemahaman Hadis Tentang Poligami (Sebuah Kajian Teologis Terhadap Hadishadis Sosial tentang Poligami). Jurnal Studi Ilmu-Ilmu Al-Qur'an Dan Hadis, 17(2), 187-206.

Sahal, M., \& Aziz, A. A. (1999). Teologi Islam Modern. Gitamedia Press.

Said, N. (2013). Teologi Islam Kontekstual-Transformatif. FIKRAH, 1(1).

Samad, M. (2016). Gerakan Moral: Dalam Upaya Revolusi Mental. Sunrise Book Store.

Saparuddin, S. (2020). Aspek-aspek Ketuhanan dalam Teologis dan Pluralitas. Dirasat Islamiah: Jurnal Kajian Keislaman, 1(1), 16-33.

Siti, R. (2016). Pemahaman Hadis Tentang Larangan Mencaci-maki Masa (Analisis Teologis).

Soetari, E. (1994). Ilmu Hadits. Amal Bakti Press.

Soetari, E. (2005). Ilmu Hadits: Kajian Riwayah dan Dirayah. Mimbar Pustaka.

Soetari, E. (2015). Syarah dan Kritik Hadis dengan Metode Tahrij: Teori dan Aplikasi (2nd ed.). Yayasan Amal Bakti Gombong Layang. 
Subadar, S. (2017). Penguatan Pendidikan Karakter (Ppk) Berbasis Higher Order Thinking Skills (HOTS). PEDAGOGIK: Jurnal Pendidikan, 4(1).

Sudarsono, S. C. (2016). Metafora Tentang Tuhan Dalam Kitab Mazmur. Sintesis, 10(1), 35-46.

Sudikan, S. Y. (2015). Pendekatan interdisipliner, multidisipliner, dan transdisipliner dalam studi sastra. Paramasastra, 2(1).

Sulaemang, S. L. (2016). Teknik Interpretasi Hadis dalam Kitab Syarah Al-Hadis. Jurnal Ilmiah Ilmu Ushuluddin, 14(2), 125-132.

Suryadilaga, M. A. (2013). Pemahaman Hadis Tentang Bencana (Sebuah Kajian Teologis terhadap Hadis-hadis tentang Bencana). ESENSIA: Jurnal Ilmu-Ilmu Ushuluddin, 14(1), 83-102.

Suryadilaga, M. A. (2017). Pembacaan Hadis dalam Perspektif Antropologi. Al Qalam, 34(2), 265286.

Suyatman, U. (2018). Teologi Lingkungan Dalam Kearifan Lokal Masyarakat Sunda. Al-Tsaqafa: Jurnal Ilmiah Peradaban Islam, 15(1), 77-88.

Sy, S. (2017). Pengaruh Hadis Dalam Ilmu Fiqih dan Teologi (Kajian Tokoh dan Pemikiran Imam Syafii). El-Furqania: Jurnal Ushuluddin Dan Ilmu-Ilmu Keislaman, 3(02), 221-233.

Syaefuddin, M. (2018). Gerakan Dakwah Cinta Tanah Air Indonesia (Strategi dan Metode Dakwah KH. Habib Luthfi Pekalongan). Jurnal Ilmu Dakwah, 37(2), 215-246.

Syafii, S. (2017). Dari ilmu tauhid/ilmu kalam ke teologi: analisis epistemologis. Jurnal Theologia, 23(1), 1-15.

Syukur, M. A. (2003). Teologi Islam terapan: upaya antisipatif terhadap hedonisme kehidupan modern. Tiga Serangkai.

Syukur, S. (2014). Rekonstruksi Teologi Islam Kajian Kritis Terhadap Usaha Pembaharuan Menuju Teologi Praktis. Jurnal THEOLOGIA, 25(2), 3-26.

Taufik, E. T. (2020). Epistemologi Syarah Hadis di Perguruan Tinggi: Diskursus Genealogis Terhadap Transmisi dan Transformasi Metode Syarah Hadis di Indonesia. Ushuluna: Jurnal Ilmu Ushuluddin, 6(2), 33-50.

Tim Penyusun. (2018). Keputusan Direktur Jenderal Pendidikan Islam Nomor 6994 Tahun 2018 tentang Agenda Riset Keagamaan Nasional (Arkan) 2018-2028.

Toshihiko, I., \& Husein, A. F. (1994). Konsep kepercayaan dalam teologi Islam: analisis semantik Iman dan Islam. Tiara Wacana Yogya.

Umar, N. (1995). Teologi Menstruasi: Antara Mitologi dan Kitab Suci. Dalam Ulumul Qur'an, 6(2).

Utami, I. B. (2018). Peran Komunitas Islam dalam Menyemangati Keagamaan para Pemuda. Anida (Aktualisasi Nuansa Ilmu Dakwah), 18(1), 105-124.

Wendry, N., Anshori, M., Majid, A., M Dalil, F. Y., \& Rahman, H. (2018). Paradigma Studi Hadis Kontemporer.

Yamani, M. T. (2015). Memahami Al-Qur'an dengan metode tafsir maudhu'i. J-PAI: Jurnal Pendidikan Agama Islam, 1(2).

Yuniarto, B. (2013). Membangun Kesadaran Warga Negara dalam Pelestarian Lingkungan. Deepublish.

Yusram, M. (2017). Hukum Meriwayatkan dan Mengamalkan Hadis Daif untuk Fadhail al-A'mal. NUKHBATUL'ULUM: Jurnal Bidang Kajian Islam, 3(1), 1-11.

Zabidi, A. (n.d.). Imam, "Kitab tentang Iman” dalam Ringkasan Shahih Bukhari, Pent. Cecep Syamsul Hari Dan Tholib Anis,(Bandung: Mizan, 2003), Cet. IX.

Zahrah, N. S. (2020). Gharib al-Hadits Sebagai Embriologi Syarah Hadits dan Transformasinya. ElAfkar: Jurnal Pemikiran Keislaman Dan Tafsir Hadis, 9(1), 127-141. 